\title{
Kratom (Mitragyna speciosa Korth) for a New Medicinal: a Review of Pharmacological and Compound Analysis
}

\author{
Adang Firmansyah ${ }^{1 *(D)}$, Melvia Sundalian ${ }^{1(D)}$, Muhammad Taufiq 1*(i) \\ 1 Sekolah Tinggi Farmasi Indonesia, Bandung, Indonesia \\ * Correspondence: adangfirmansyah@stfi.ac.id (A.F.); m.taufiqhasibuan@gmail.com (M.T.);
}

Scopus Author ID 57216094882

Received: 25.08.2020; Revised: 12.09.2020; Accepted: 14.09.2020; Published: 16.09.2020

\begin{abstract}
Mitragyna speciosa Korth. (Rubiaceae) a tree found in Southeast Asia (Thailand, Indonesia, Malaysia, Myanmar, Philippines, and Papua New Guinea. Traditionally, the Mitragyna speciosa was used to alleviate pain, hypertension, cough, diarrhea, and as a substitute for morphine in treating addicts. Association of Southeast Asian Nations refers to kratom as a drug. Kratom contains more than 40 types of alkaloids, including Mitragynine speciosa, as many as (66.2\%) and their derivatives, speciogynine $(6.6 \%)$, speciociliatine $(0.8 \%)$, paynantheine $(8.6 \%)$, 7-hydroxymitragynine $(2 \%)$. The article was created to provide information related to the pharmacological effects of kratom, kratom compound analysis, and the potential of compounds from kratom to become new drugs. The method used in this research is to review and analyze kratom articles from research papers, bibliographic reviews, and case reports included, research conducted in Indonesia and in English. The main purpose of this review is not only to understand the chemical content, benefits of kratom, and analytical methodologies for analysis, but also the use of kratom secondary metabolites as therapeutic drugs and the side effects caused by kratom, to help health professionals assess the content of compounds from kratom worthy of being new drugs.
\end{abstract}

Keywords: Kratom; Mitragyna speciosa Korth; effects; case report; toxicity; benefits; new drugs.

(C) 2020 by the authors. This article is an open-access article distributed under the terms and conditions of the Creative Commons Attribution (CC BY) license (https://creativecommons.org/licenses/by/4.0/).

\section{Introduction}

Mitragyna speciosa Korth. (Rubiaceae) a tree found in Southeast Asia (Thailand, Indonesia, Malaysia, Myanmar, Philippines, and Papua New Guinea) has proven to have medicinally relevant alkaloids within its leaves [1]. Kratom, also known as Mitragyna speciosa, is extracted from the leaves of evergreen, deciduous tree native to Southeast-Asia and was originally described in 1839 by botanist Pieter Willem Korthals. Kratom has been widely used in Southeast Asia for hundreds of years [2]. In Indonesia, kratom use typically involves the ingestion of the plant's raw leaves or consumption of teas that are brewed or steeped from the leaves [3]. Traditionally, the Mitragyna speciosa was used to alleviate pain, hypertension, cough, diarrhea, and as a substitute for morphine in treating addicts [4-5].

Mature leaves of Mitragyna speciosa are recognized as a rich source of alkaloids, and mitragynine was obtained as the major constituent, which is $66.2 \%$ based on the crude base and followed by its analogs speciogynine, speciociliatine, and paynantheine [4-12]. Mitragynine compounds in kratom have one of the properties as an antinociceptive [13]. Mitragynine produced antinociceptive effects similar to the reference opioid agonists when administered intraperitoneal and oral routes [14]. Supported by the results of research Yue et 
al. (2018), which states that mitragynine has an affinity of 16 times greater with opioid receptors than opioids and opioid receptors, its affinity with opioid receptors is about 200 times that of morphine, so mitragynine shows its potential as an opioid analgesic [15]. Its derivative 7-hydroxymitragynine shows a much more potent antinociceptive effect in mice than does either mitragynine or morphine [7]. According to a survey conducted by Swogger et al. (2018), kratom effects similar to morphine, but the side effects it produces are smaller than other similar opioid substances [16]. Other pharmacological effects produced by kratom leaves have been studied as analgesics [4], antipyretic [17], sedatives, stimulants, and depressants [18], antiinflammatory [19], antidiarrheal [20], antioxidant and antimicrobial [21]. Kratom has a high economic value for 5 grams kratom extract, it costs $\$ 34.99$, while the ultra enhanced form is more expensive, at 5 grams price $\$ 45.99$ [22].

This article aims to examine kratom plants so that they can provide information to the public and related institutions about the hidden benefits of kratom leaves, kratom abuse, content analysis of kratom compounds, the pharmacological effects, and potential as raw materials for new medicines in the pharmaceutical field.

\section{Materials and Methods}

A search for this review was done online at Pubmed, Google Scholar, and the European Monitoring Centre for Drugs and Drug Addiction (EMCDDA) websites. Research papers, bibliographic reviews, and case reports were included, the research done in Indonesia and in English. The search strings used were Mitragyna speciosa, Mitragyna speciosa extract, Mitragyna speciosa and toxicity, kratom benefit and risk, kratom pharmacology, Mitragyna abuse, kratom deaths, and kratom analysis. The search was performed between January of 2020 and July of 2020. No publishing date restrictions were used. Among the 140 papers, we selected 78 publications based on the search criteria for Mitragyna speciosa Korth, kratom extract, kratom, qualitative, methodology, general review, updates. Those publications comprised case reports, toxicity, dependence, pharmacology, pharmacokinetics, analysis of kratom leaves. Although there is a risk of bias because our search was intended to demonstrate mostly risks (toxicity) of kratom (Mitragyna speciosa Korth) use and to a lesser degree comparing benefits and risks of the leave, we did review kratom biochemical benefits that we describe in the result section where we present the most supported publications representing the most advanced and recent findings of kratom.

\section{Results and Discussion}

\subsection{Case report.}

Kratom is consumed worldwide for stimulant effects and as a substitute for opioids (in the form of tea, chewed, sucked, or digested in capsules). Several case reports have been related to kratom related to psychosis, seizures, intrahepatic cholestasis, other medical conditions, and death [23]. Osborne et al. (2019) case report of use kratom a 47-year-old male who developed fatigue, pruritus, and abnormal liver tests approximately 21 days after beginning kratom [24]. The patient was diagnosed with drug-induced liver injury (DILI) caused by kratom. Nine months after his liver tests returned to normal, he took kratom again, and after a latency of 2 days, he developed fatigue, pruritus, and loss of appetite along with abnormal liver tests (with the same biochemical profile as previously), consistent with a positive rechallenge. Aggarwal et al. (2018) case report of a 26-year-old man who was brought into our emergency department 
in cardiorespiratory arrest, having taken kratom $24 \mathrm{~h}$ previously [25]. Despite multi-organ support, he deteriorated and died from cardiorespiratory failure and hypoxic brain damage 12 hours later. Lipid emulsion was given, with significant temporary improvement in cardiorespiratory failure. Nelsen et al. (2010) also reported a case of a 64-year-old man witnessed a seizure at home after consumption of kratom. The analysis showed that the concentration of mitragynine in urine was $167 \pm 15 \mathrm{ng} / \mathrm{ml}$ [26]. Case reports involving users who consumed kratom leaves in powder form, with 5 cases of kratom leaf use along with other drugs such as venlafaxine, diphenhydramine, and mirtazapine in patients who died of suspected excessive doses of kratom leaves [27]. Tungtananuwat et al. (2010) reported the case of the death of a 21-year-old man suspected of having an overdose of kratom leaves [28]. The following substances are found in blood and urine samples: mitragynine (alkaloids found in kratom; Mitragyna speciosa leaves), caffeine, diphenhydramine, alprazolam, nortriptyline, methadone, tramadol, methamphetamine, and some of its metabolites. In this case, the cause of death might be caused by multidrug poisoning additional side effects, especially the Central Nervous System (CNS) and respiratory depression. Besides that, a case report on the use of kratom with other substances was also reported by Kronstrand et al. (2011), which found 9 cases of death from consuming mitragynine and O-desme thyltramadol [29]. From the results of the analysis in the blood found the concentration of mitragynine in the blood ranged from 0.02 to $0.18 \mu \mathrm{g} / \mathrm{g}$, and O-desmethyltramadol ranged from 0.4 to $4.3 \mu \mathrm{g} / \mathrm{g}$. Karinen et al. (2014) reported a case of death of a middle-aged man due to a kratom overdose with post-mortem peripheral blood results found mitragynine $1.06 \mathrm{mg} / \mathrm{L}$, 7-hydroxymitragynine $0.15 \mathrm{mg} / \mathrm{L}$ [30]. Additionally, zopiclone $0.043 \mathrm{mg} / \mathrm{L}$, citalopram $0.36 \mathrm{mg} / \mathrm{L}$, and lamotrigine $5.4 \mathrm{mg} / \mathrm{L}$ were detected in the blood but in the therapeutic concentration range. Holler et al. (2011) found cases of death involving the abuse of propylhexedrine and mitragynine [31]. Toxicological results revealed the presence of propylhexedrine $1.7 \mathrm{mg} / \mathrm{L}$ and mitragynine $0.39 \mathrm{mg} / \mathrm{L}$ in his blood. The cause of death is propylhexedrine poisoning, and the manner of death is due to an accident. Mitragynine might have contributed as well, but because there are no published data for drug concentrations, medical examiners also did not include mitragynine toxicity in causes of death. The average case report of kratom use with the addition of other substances or just the use of kratom itself causes, among others, psychosis, seizures, intrahepatic cholestasis, other medical conditions, until death due to the use of kratom leaf doses has not been proven and standardized [32]. The reasons for using kratom include reasons for use-self-medication, recreation, relaxation, body-building, avoiding positive drug tests [33].

\subsection{Toxicity.}

From the literature study conducted, there is still little information about the safe dosage range of using kratom leaves so that it can cause toxic effects to cause death. As in the study conducted by Moklas et al. (2008), testing the level of toxicity of the alkaloid extract of Mitragyna speciosa against saltwater shrimp obtained the result of moderate toxicity to the brine of 50 shrimp larvae with LC values at $62 \mu \mathrm{l} / \mathrm{ml}$ [18]. Azizi et al. (2010) also tested the toxicity level of the alkaloid extract of Mitragyna speciosa on mice reporting a lethal effect of a total of $200 \mathrm{mg} / \mathrm{kg}$ [34]. The same study also carried out by Harizal et al. (2010) reported that Mitragyna speciosa methanol extract increased rat blood pressure (systolic: $147.4 \pm 1.01$, $131.64 \pm 4.94$ and $137.8 \pm 4.46$ ) after each dose of 100,500 , and $1000 \mathrm{mg} / \mathrm{kg}$, respectively [35]. No deaths were recorded after 14 days of treatment. However, it significantly increases one's blood pressure hours after administration, and the highest dose of the extract also induces 
acute severe hepatotoxicity and mild nephrotoxicity after single-dose administration. Sabetghadam et al. (2013) conducted a study on mitragynine toxicity to mice showing that mitragynine was relatively safe at lower sub-chronic doses $(1-10 \mathrm{mg} / \mathrm{kg})$ but showed toxicity at the highest dose (sub-chronic 28 days: $100 \mathrm{mg} / \mathrm{kg}$ ) [36]. This is confirmed by histopathological changes in the liver, kidneys, and brain, as well as hematological and biochemical changes.

\subsection{Dependence.}

According to a research survey conducted by Singh et al. (2014) of 293 kratom users reported that more than half of regular users ( $>6$ months of use) had severe kratom dependence, while $45 \%$ showed mild kratom dependence [37]. Physical withdrawal symptoms commonly experienced include muscle spasms and pain, sleeping difficulty, watery eyes/nose, hot flashes, fever, decreased appetite, and diarrhea. Psychological withdrawal symptoms commonly reported were restlessness, tension, anger, sadness, and nervousness. McWhirter et al. (2010) study reported that kratom dependency syndrome is caused by the activity of short-acting opioid receptor agonists and shows that dihydrocodeine and lofexidine are effective in supporting detoxification [38]. Warner et al. (2016) also revealed that stimulant and dosedependent effects of drugs do exist, but growing concerns about the effects of drugs and safety of use have generated national and international attention mainly due to increased hospital visits and deaths in several countries that are allegedly caused by kratom plant extracts [9]. The main active alkaloid substances in kratom, mitragynine, and 7-hydroxymitragynine, present with a variety of CNS stimulant and depressant effects that are mediated mainly through monoaminergic and opioid receptors.

In the research Yusoff et al. (2016) described the profile of addiction and cognitive impairment in the administration of acute and chronic mitragynine, which is very similar to morphine [39]. Chronic mitragynine administration causes passive activity disorders and object recognition learning. Overall, these findings provide evidence of the potential for addiction to cognitive impairment for mitragynine, which suggests classification as a dangerous drug. But the research of Hemby et al. (2019) states that mitragynine has no potential for abuse and reduces morphine intake, a desirable characteristic of pharmacotherapy candidates for opiate addiction and withdrawal, whereas 7-hydroxymitragynine should be considered a kratom constituent with a high potential for abuse that can also increase opiate withdrawal [40]. The other studies have also examined kratom usage patterns, reported effects, and explored their potential to cause dependence. Ahmad et al. (2012) research using face-to-face interviews was conducted using a structured questionnaire on 562 respondents [41]. The response rate is $91 \%$. The majority of respondents (88\%) reported daily kratom use. Only the level of education has a statistically significant relationship with the ability to stop or not stop using kratom. Overall, kratom user performance was compared to control participants, and high performance (> 3 glasses per day) as well as low ( $\leq 3$ glasses per day) kratom used groups, comparable in all neuropsychological domains [42]. Those who consumed higher quantities of kratom tea daily ( $\geq 4$ glasses) had higher odds of reporting a longer duration of kratom use history, higher frequency of daily kratom use ( $\geq 4$ times), and were more likely to experience moderate symptoms of depression during kratom cessation than those who consumed between one and three glasses of kratom tea per day. Cessation from regular and long-term kratom tea consumption was not associated with symptoms of high anxiety or depression [43]. Regular and higher (three or more glasses) consumption of kratom decoction did not appear to cause 
significant constipation problems, but users were prone to severe fatigue during kratom cessation [44].

\subsection{Pharmacological activities.}

The use of kratom or mitragynine extracts and their derivatives at certain doses will have various pharmacological effects, as summarized in Table 1.

Table 1. Research related to the pharmacological activity of kratom leaves.

\begin{tabular}{|c|c|c|c|}
\hline \multicolumn{4}{|c|}{ ANALGESIC } \\
\hline $\begin{array}{l}\text { Comparative effects of Mitragyna } \\
\text { speciosa extract, mitragynine, and } \\
\text { opioid agonists on thermal } \\
\text { nociception in rats. }\end{array}$ & $\begin{array}{l}\text { Kratom } \\
\text { Extract }\end{array}$ & $\begin{array}{l}\text { Test articles were vehicle, } 6 \mathrm{mg} / \mathrm{kg} \text { oxycodone, } 300 \\
\mathrm{mg} / \mathrm{kg} \text { Mitragyna speciosa extract, or } 100 \mathrm{mg} / \mathrm{kg} \\
\text { mitragynine with hotplate tests conducted } 30 \text { and } 60 \\
\text { min after administration. Mitragynine produced } \\
\text { antinociceptive effects similar to the reference opioid } \\
\text { agonists when administered IP and PO routes. }\end{array}$ & [14] \\
\hline $\begin{array}{l}\text { Effects of the extracts from } \\
\text { Mitragyna speciosa Korth. leaves } \\
\text { on analgesic and behavioral } \\
\text { activities in experimental animals }\end{array}$ & $\begin{array}{l}\text { Kratom } \\
\text { Extract }\end{array}$ & $\begin{array}{l}\text { The alkaloid extract from Mitragyna speciosa also } \\
\text { increased response latency with a dose of } 20 \mathrm{mg} / \mathrm{kg} \text { but } \\
\text { was less strong than methanol extract }(100 \mathrm{mg} / \mathrm{kg} \text { ) in } \\
\text { mice (compare } 5-10 \mathrm{mg} / \mathrm{kg} \text { of alkaloid extract with } \\
\text { those corresponding to } 200 \mathrm{mg} / \mathrm{kg} \text { of methanol } \\
\text { extract). These results indicate that the methanol and } \\
\text { alkaloid extracts of Mitragyna speciosa leaves have } \\
\text { the most important analgesic activity on opioid } \\
\text { receptors in the supraspinal opioid system. }\end{array}$ & [4] \\
\hline $\begin{array}{l}\text { Chemistry and Pharmacology of } \\
\text { Analgesic Indole Alkaloids from } \\
\text { the Rubiaceous Plant, Mitragyna } \\
\text { speciosa }\end{array}$ & Mitragynine & $\begin{array}{l}\text { The activity of mitragynine opioid agonists, with the } \\
\text { mechanism underlying analgesic activity clarified, } \\
\text { shows potent antinociceptive activity in rats. }\end{array}$ & [6] \\
\hline $\begin{array}{l}\text { Antinociceptive Action of Isolated } \\
\text { Mitragynine from Mitragyna } \\
\text { speciosa through Activation of } \\
\text { Opioid Receptor System. }\end{array}$ & Mitragynine & $\begin{array}{l}\text { In this study, } 35 \mathrm{mg} / \mathrm{kg} \text { of mitragynine showed a } \\
\text { significant increase in latency time, and this dose was } \\
\text { used in antagonist receptor studies (antinociceptive } \\
\text { effect). }\end{array}$ & [13] \\
\hline $\begin{array}{l}\text { Anti-Inflammatory } \\
\text { Antinociceptive Effects } r \text { of } \\
\text { Mitragyna speciosa Korth } \\
\text { Methanolic Extract. }\end{array}$ & $\begin{array}{l}\text { Kratom } \\
\text { Extract }\end{array}$ & $\begin{array}{l}\text { Results showed that intraperitoneal administration of } \\
\text { the extract at doses of } 100 \text { and } 200 \mathrm{mg} / \mathrm{kg} \text { produced } \\
\text { significant dose-dependent activity in all of the } \\
\text { nociceptive models evaluated. With the formalin test, } \\
\text { the antinociceptive activity in mice was inhibited only } \\
\text { at the highest dose of the extract }(200 \mathrm{mg} / \mathrm{kg}) \text {. }\end{array}$ & [19] \\
\hline \multicolumn{4}{|c|}{ SEDATIVE } \\
\hline $\begin{array}{l}\text { Effects of an alkaloid-rich extract } \\
\text { from Mitragyna speciosa leaves } \\
\text { and fluoxetine on sleep profiles, } \\
\text { EEG spectral frequency and } \\
\text { ethanol with drawal symptomsin } \\
\text { rats. }\end{array}$ & $\begin{array}{l}\text { Kratom } \\
\text { Extract }\end{array}$ & $\begin{array}{l}\text { Alkaloid extract from Kratom }(60 \mathrm{mg} / \mathrm{kg}) \text { was found } \\
\text { to significantly attenuate ethanol withdrawal-induced } \\
\text { hyperexcitability (increases gamma activity) in both } \\
\text { cortices and to reduce locomotor activity (sedative). }\end{array}$ & [45] \\
\hline $\begin{array}{l}\text { Test of Sedative Effects of } \mathrm{N}- \\
\text { Hexane Extract from Kratom } \\
\text { (Mitragyna speciosa Korth) } \\
\text { Leaves on Male Mice. }\end{array}$ & $\begin{array}{l}\text { Kratom } \\
\text { Extract }\end{array}$ & $\begin{array}{l}\text { The results showed that } n \text {-hexane extract had a } \\
\text { sedative effect contained the compound group of } \\
\text { alkaloids, glycosides, steroids, and flavonoids. The } \\
\text { dosage } 4(96 \mathrm{mg} / \mathrm{kg} \text { BW) of } n \text {-hexane extract of } \\
\text { kratom leaves gave sedative effects better than } \\
\text { diazepam. }\end{array}$ & [46] \\
\hline $\begin{array}{l}\text { The Test On The Sedative Effect } \\
\text { Of Kratom (Mitragyna speciosa } \\
\text { Korth.) Leaves Infusa To Male } \\
\text { Balb/C Strain Mice }\end{array}$ & $\begin{array}{l}\text { Kratom } \\
\text { Extract }\end{array}$ & $\begin{array}{l}\text { Based on the result, all of kratom leaves infusa dosages } \\
\text { has a sedative effect, which is the most effective dose } \\
\text { kratom leaves infusa at a dose of } 7.80 \mathrm{~g} / \mathrm{Kg} \mathrm{BW} \text {. But } \\
\text { the sedative effect still below diazepam. }\end{array}$ & [47] \\
\hline $\begin{array}{l}\text { Sedative Effect Test of Kratom } \\
\text { (Mitragyna speciosa Korth) } \\
\text { Ethanolic Extract Extract Leaves } \\
\text { on Balb/C strain male mice }\end{array}$ & $\begin{array}{l}\text { Kratom } \\
\text { Extract }\end{array}$ & $\begin{array}{l}\text { The results show, there are sedative effects at doses of } \\
27.20 \mathrm{mg} / 20 \mathrm{~g} \mathrm{BW}, 54.39 \mathrm{mg} / 20 \mathrm{~g} \mathrm{BW} \text {, and } 108.78 \\
\mathrm{mg} / 20 \mathrm{~g} \mathrm{BW} \text {, which the all dose are greater potential } \\
\text { than the positive control group (diazepam). The } \\
\text { effective dose of fraction ethanol of kratom leaf is } \\
27.20 \mathrm{mg} / 20 \mathrm{~g} \mathrm{BW} \text {. }\end{array}$ & [48] \\
\hline \multicolumn{4}{|c|}{ ANTIOBESITY } \\
\hline $\begin{array}{l}\text { Acute and long-term effects of } \\
\text { alkaloid extract of Mitragyna } \\
\text { speciosa on food and water intake } \\
\text { and body weight in rats }\end{array}$ & $\begin{array}{l}\text { Kratom } \\
\text { Extract }\end{array}$ & $\begin{array}{l}\text { Acute administration of Mitragyna speciose extract } \\
(45 \text { and } 50 \mathrm{mg} / \mathrm{kg} \text { ) significantly resulted in dose- } \\
\text { dependent decreases in food and water intakes } \\
(\mathrm{Pb} 0.05) \text { in rats. Prolonged suppressing effects were }\end{array}$ & [49] \\
\hline
\end{tabular}




\begin{tabular}{|c|c|c|c|}
\hline & & $\begin{array}{l}\text { observed following administration of the Mitragyna } \\
\text { speciose extract }(40 \mathrm{mg} / \mathrm{kg}) \text { for } 60 \text { consecutive days. } \\
\text { Moreover, the long-term administration also } \\
\text { significantly suppressed weight gaining. }\end{array}$ & \\
\hline \multicolumn{4}{|c|}{ MEMORY } \\
\hline $\begin{array}{l}\text { An examination of the } \\
\text { consequences of chronic exposure } \\
\text { to Mitragyna speciosa during } \\
\text { adolescence on learning and } \\
\text { memory in adulthood }\end{array}$ & $\begin{array}{l}\text { Kratom } \\
\text { Extract }\end{array}$ & $\begin{array}{l}\text { In this experiment, adolescent rats were given repeated } \\
\text { saline injections, } 15 \mathrm{mg} / \mathrm{kg} \text {, or } 50 \mathrm{mg} / \mathrm{kg} \text { extract of } \\
\text { Mitragyna speciosa. After animals reach } 107 \text { days, they } \\
\text { are assessed for general activity. The results of the study } \\
\text { show that chronic exposure to alkaloids during } \\
\text { adolescence can produce subtle changes but affect } \\
\text { memory performance and work in adulthood, long after } \\
\text { exposure to Kratom has ended. }\end{array}$ & [50] \\
\hline \multicolumn{4}{|c|}{ BREAST ANTICANCER } \\
\hline $\begin{array}{l}\text { Characterization of cytotoxic } \\
\text { compounds from the ethrat acetate } \\
\text { fraction of Kratom (Mitragyna } \\
\text { speciosa Korth) leaves and their } \\
\text { activity on T47d breast cancer } \\
\text { cells }\end{array}$ & $\begin{array}{l}\text { Kratom } \\
\text { Extract }\end{array}$ & $\begin{array}{l}\text { Based on the research that has been done, it can be } \\
\text { concluded that the cytotoxic compounds obtained } \\
\text { from the ethyl acetate fraction are classified as } \\
\text { moderate cytotoxic against T47D breast cancer cells } \\
\text { with an IC50 value of } 161.67 \mu \mathrm{g} / \mathrm{mL} \text {. }\end{array}$ & [51] \\
\hline \multicolumn{4}{|c|}{ ANTINOSISEPTIVE } \\
\hline $\begin{array}{l}\text { Fos-like immunoreactivity in rat } \\
\text { dorsal raphe nuclei induced by } \\
\text { alkaloid extract of Mitragyna } \\
\text { speciosa. }\end{array}$ & $\begin{array}{l}\text { Kratom } \\
\text { Extract }\end{array}$ & $\begin{array}{l}\text { The results showed that a single injection (dose of } 60 \\
\text { or } 90 \mathrm{mg} / \mathrm{kg} \text { ) significantly decreased the time of } \\
\text { immobility in FST. These findings indicate that } \\
\text { Mitragyna speciose extract has a stimulating effect on } \\
\text { the dorsal raphe nucleus and antidepressant activity. } \\
\text { Stimulation of this area of the brain has been known to } \\
\text { cause antinosisepsi. }\end{array}$ & [52] \\
\hline $\begin{array}{l}\text { The evaluation of antinociceptive } \\
\text { activity of alkaloid, methanolic, } \\
\text { and aqueous extracts of Malaysian } \\
\text { Mitragyna speciosa Korth leaves } \\
\text { in rats. }\end{array}$ & $\begin{array}{l}\text { Kratom } \\
\text { Extract }\end{array}$ & $\begin{array}{l}\text { Results showed that oral administration of the alkaloid } \\
(20 \mathrm{mg} / \mathrm{kg}) \text {, methanolic }(200 \mathrm{mg} / \mathrm{kg}) \text {, and aqueous } \\
(400 \mathrm{mg} / \mathrm{kg}) \text { extracts significantly prolonged the } \\
\text { latency of nociceptive was blocked by naloxone. In } \\
\text { conclusion, these results suggest the presence of an } \\
\text { antinociceptive effect in various extracts of Malaysian } \\
\text { Mitragyna speciosa leaves. }\end{array}$ & [53] \\
\hline $\begin{array}{l}\text { Antinociceptive Activity of } \\
\text { Aqueous Fraction of Kratom } \\
\text { Leaves Mitragyna speciosa } \\
\text { Korth.) on Male Swiss Albino } \\
\text { Mice }\end{array}$ & $\begin{array}{l}\text { Kratom } \\
\text { Extract }\end{array}$ & $\begin{array}{l}\text { The result showed that the aqueous fraction at the dose } \\
\text { of } 140,280, \text { and } 560 \mathrm{mg} / \mathrm{kgBW} \text { significantly } \\
\text { differentiate with the negative control group and } \\
\text { positive control group. The antinociceptive effect } \\
\text { increases with increasing doses. The three doses } \\
\text { showed that the antinociceptive effect was no better } \\
\text { than the positive control (morphine). }\end{array}$ & [54] \\
\hline $\begin{array}{l}\text { Antinociceptive } \quad \text { Activity of } \\
\text { Dichloromethane } \\
\text { Kratom Leaves } \quad \text { (Mitragyna } \\
\text { speciosa Korth.) by Oral Route In } \\
\text { Male Swiss Mice }\end{array}$ & $\begin{array}{l}\text { Kratom } \\
\text { Extract }\end{array}$ & $\begin{array}{l}\text { The purpose of this research was to investigate the } \\
\text { antinociceptive effect of dicholoromethane fraction } \\
\text { from kratom leaf and determine the percentage of } \\
\text { antinociceptive activity on male Swiss mice. Result } \\
\text { data were analyzed using One Way ANOVA and Post } \\
\text { Hoc Test LSD. It showed the antinociceptive effect of } \\
\text { dichloromethane fraction at dose } 70,140 \text {, and } 280 \\
\mathrm{mg} / \mathrm{kgBW} \text { were significantly difference (p<0.05) } \\
\text { with the normal group. The conclusion of this study } \\
\text { is the dichloromethane fraction of kratom leaf has } \\
\text { antinociceptive activity. The percentage of } \\
\text { antinociceptive from the fraction group at dose } 280 \\
\text { mg/kgBW was higher than the other two dose-groups } \\
(140 \text { and } 70 \mathrm{mg} / \mathrm{kgBW}) \text {. }\end{array}$ & [55] \\
\hline $\begin{array}{l}\text { Comparative effects of Mitragyna } \\
\text { speciosa extract, mitragynine, and } \\
\text { opioid agonists on thermal } \\
\text { nociception in rats. }\end{array}$ & $\begin{array}{l}\text { Kratom } \\
\text { Extract }\end{array}$ & $\begin{array}{l}\text { Mitragynine produced antinociceptive effects similar } \\
\text { to the reference opioid agonists when administered IP } \\
\text { and PO routes. }\end{array}$ & [14] \\
\hline $\begin{array}{l}\text { Antinociception, tolerance and } \\
\text { withdrawal symptoms induced by } \\
\text { 7-hydroxymitragynine, an } \\
\text { alkaloid from the Thai medicinal } \\
\text { herb Mitragyna speciosa }\end{array}$ & $\begin{array}{l}\text { 7- } \\
\text { hydroxymitra } \\
\text { gynine }\end{array}$ & $\begin{array}{l}\text { In the present study, investigates the opioid receptor } \\
\text { subtype responsible for the analgesic effect of this } \\
\text { compound. Subcutaneous (s.c.) administration of } 7 \text { - } \\
\text { hydroxymitragynine ( } 10 \mathrm{mg} / \mathrm{kg} \text {, twice daily for } 5 \\
\text { days) produced a potent antinociceptive effect mainly } \\
\text { through activation of A-opioid receptors. Tolerance } \\
\text { to the antinociceptive effect of } 7 \text {-hydroxymitragynine } \\
\text { developed as occurs to morphine. 7- } \\
\text { Hydroxymitragynine exhibited a potent }\end{array}$ & [56] \\
\hline
\end{tabular}




\begin{tabular}{|c|c|c|c|}
\hline & & $\begin{array}{l}\text { antinociceptive effect based on the activation of A- } \\
\text { opioid receptors and its morphine-like } \\
\text { pharmacological character, but } \\
\text { hydroxymitragynine is structurally different from } \\
\text { morphine. }\end{array}$ & \\
\hline $\begin{array}{l}\text { Central antinociceptive effects of } \\
\text { mitragynine in mice: contribution } \\
\text { of Descending noradrenergic and } \\
\text { serotonergic systems }\end{array}$ & Mitragynine & $\begin{array}{l}\text { This study investigated the roles of central } \\
\text { monoaminergic systems in the antinociceptive action } \\
\text { of mitragynine. Mitragynine }(1.0-10 \mu \mathrm{g}) \text { injected } \\
\text { i.c.v. exerted a dose-dependent antinociceptive } \\
\text { activity in both tests. in this study, it was revealed that } \\
\text { mitragynine causes antinociception by stimulating } \alpha_{2}- \\
\text { adrenoceptor and / or blocking 5-HT receptors in } \\
\text { mice but has lower antinociceptive activity than } \\
\text { morphine. }\end{array}$ & [57] \\
\hline $\begin{array}{l}\text { Involvement of } \mu \text {-opioid receptors } \\
\text { in antinociception and inhibition } \\
\text { of gastrointestinal transit induced } \\
\text { by 7-hydroxymitragynine, isolated } \\
\text { from Thai herbal medicine } \\
\text { Mitragyna speciosa. }\end{array}$ & $\begin{array}{l}\text { 7- } \\
\text { hydroxymitra } \\
\text { gynine }\end{array}$ & $\begin{array}{l}\text { The present study investigated the mechanism of } \\
\text { antinociception 7-hydroxymitragynine, and } \\
\text { compared its effects with those of morphine. When } \\
\text { administered subcutaneously to mice, 7- } \\
\text { hydroxymitragynine produced antinociceptive effects } \\
\text { about } 5.7 \text { and } 4.4 \text { times more potent than those of } \\
\text { morphine in the tail-flick (ED50 }=0.80 \mathrm{mg} / \mathrm{kg} \text { ) and } \\
\text { hotplate }(\mathrm{ED} 50=0.93 \mathrm{mg} / \mathrm{kg} \text { ) tests, respectively. }\end{array}$ & [58] \\
\hline $\begin{array}{l}\text { Antinociceptive effect of } 7- \\
\text { hydroxymitragynine in mice: } \\
\text { Discovery of an orally active } \\
\text { opioid analgesic from the Thai } \\
\text { medicinal herb Mitragyna } \\
\text { speciosa }\end{array}$ & $\begin{array}{l}\text { 7- } \\
\text { hydroxymitra } \\
\text { gynine }\end{array}$ & $\begin{array}{l}\text { When orally administered, 7-hydroxymitragynine (5- } \\
10 \mathrm{mg} / \mathrm{kg} \text { ) showed potent antinociceptive activities in } \\
\text { tail-flick and hotplate tests. In contrast, only weak } \\
\text { antinociception was observed in the case of oral } \\
\text { administration of morphine at a dose of } 20 \mathrm{mg} / \mathrm{kg} \text {. It } \\
\text { was found that } 7 \text {-hydroxymitragynine is a novel } \\
\text { opioid agonist that is structurally different from the } \\
\text { other opioid agonists and has potent analgesic activity } \\
\text { when orally administered. }\end{array}$ & [59] \\
\hline $\begin{array}{l}\text { MGM-9 [(E)-methyl 2-(3-ethyl- } \\
\text { 7a,12a-(epoxyethanoxy)-9-fluoro- } \\
\text { 1,2,3,4,6,7,12,12b-octahydro-8- } \\
\text { methoxyindolo[2,3-a]quinolizin- } \\
\text { 2-yl)-3-methoxyacrylate], a } \\
\text { derivative of the indole alkaloid } \\
\text { mitragynine: A novel dual-acting } \\
\text { m- and k-opioid agonist with } \\
\text { potent antinociceptive and weak } \\
\text { rewarding effects in mice. }\end{array}$ & MGM-9 & $\begin{array}{l}\text { Pemberian MGM-9 secara subkutan dan oral } \\
\text { menghasilkan antinosiseptif yang kuat efek dalam tes } \\
\text { ekor tikus, hot-plate, dan menggeliat. Ketika } \\
\text { diberikan secara oral, efek antinociceptive dari } \\
\text { MGM-9 adalah tujuh hingga } 22 \text { kali lebih kuat } \\
\text { daripada morfin. }\end{array}$ & [60] \\
\hline \multicolumn{4}{|c|}{ NEUROMUSCULAR } \\
\hline $\begin{array}{l}\text { The neuromuscular blockade } \\
\text { produced by pure alkaloid, } \\
\text { mitragynine and methanol extract } \\
\text { of kratom leaves (Mitragyna } \\
\text { speciosa Korth.). }\end{array}$ & $\begin{array}{l}\text { Kratom } \\
\text { Extract }\end{array}$ & $\begin{array}{l}\text { Kratom methanolic extract present at } 0.1-1 \mathrm{mg} / \mathrm{mL} \\
\text { and mitragynine }(0.0156 \mathrm{mg} / \mathrm{mL}) \text { decreased the } \\
\text { muscle twitch on the isolated phrenic nerve- } \\
\text { hemidiaphragm and hemidiaphragm preparation. } \\
\text { Muscle relaxation caused by kratom extract } \\
(1 \mathrm{mg} / \mathrm{mL}) \text { was greater than the effect of mitragynine. } \\
\text { High concentrations of kratom extract }(10-40 \mathrm{mg} / \mathrm{mL}) \\
\text { and mitragynine ( } 2 \mathrm{mg} / \mathrm{mL}) \text { blocked the nerve } \\
\text { conduction, amplitude, and duration of a compound } \\
\text { nerve action potential. }\end{array}$ & [61] \\
\hline $\begin{array}{l}\text { Inhibitory effects of kratom leaf } \\
\text { extract (Mitragyna speciosa } \\
\text { Korth.) on the rat gastrointestinal } \\
\text { tract. }\end{array}$ & $\begin{array}{l}\text { Kratom } \\
\text { Extract }\end{array}$ & $\begin{array}{l}\text { Kratom extract reduces muscle contraction in } \\
\text { phrenics, which reduces phrenic nerve- } \\
\text { hemidiaphragm causing muscle relaxation at } \\
\text { concentrations greater than } 0.1 \mathrm{mg} / \mathrm{mL} \text {, and at the } \\
\text { highest concentration used }(1 \mathrm{mg} / \mathrm{mL}) \text {, causes perfect } \\
\text { contraction, about } 15 \text { minutes. }\end{array}$ & {$[62]$} \\
\hline \multicolumn{4}{|c|}{ INDUKSI CYP450 } \\
\hline $\begin{array}{l}\text { Mitragyna speciosa Korth leaves } \\
\text { extracts induced the CYP } 450 \\
\text { catalyzed aminopyrine-N- } \\
\text { demethylase (APND) and UDP- } \\
\text { glucuronosyl transferase (UGT) } \\
\text { activities in male Sprague-Dawley } \\
\text { rat livers. }\end{array}$ & $\begin{array}{l}\text { Kratom } \\
\text { Extract }\end{array}$ & $\begin{array}{l}\text { The assessment of the enzyme activity was conducted } \\
\text { using spectrophotometric methods. In vitro, the } \mathrm{IC}_{50} \\
\text { value could only be obtained for the methanolic extract } \\
\text { in APND study ( } 595.30 \pm 30.78 \mu \mathrm{g} / \mathrm{mL} \text { ) and not in } \\
\text { other studies due to the enzyme percentage inhibitions } \\
\text { being }<70 \% \text {. In contrast to the in vitro study, the oral } \\
\text { treatment of male Sprague-Dawley rats for } 14 \text { days } \\
\text { with } 50,100 \text {, and } 200 \mathrm{mg} / \mathrm{kg} \text { of methanolic and } \\
\text { aqueous extracts and with } 5,10 \text {, and } 20 \mathrm{mg} / \mathrm{kg} \text { of total } \\
\text { alkaloid extract showed a profound increment on the } \\
\text { APND and UGT activities. }\end{array}$ & [63] \\
\hline
\end{tabular}




\begin{tabular}{|c|c|c|c|}
\hline \multicolumn{3}{|c|}{ ANTIINFLAMATION } & \multirow[b]{2}{*}{ [19] } \\
\hline 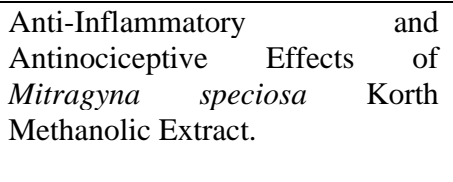 & $\begin{array}{l}\text { Kratom } \\
\text { Extract }\end{array}$ & $\begin{array}{l}\text { The study showed that intraperitoneal administration } \\
\text { of the methanol extract of } M \text {. speciosa ( } 100 \text { and } 200 \\
\mathrm{mg} / \mathrm{kg} \text { ) significantly and dose-dependently suppressed } \\
\text { the development of carrageenan-induced rat paw } \\
\text { edema. }\end{array}$ & \\
\hline $\begin{array}{l}\text { Chemical constituents and nitric } \\
\text { oxide inhibitory activity of } \\
\text { supercritical carbon dioxide } \\
\text { extracts from Mitragyna speciosa } \\
\text { leaves }\end{array}$ & $\begin{array}{l}\text { Kratom } \\
\text { Extract }\end{array}$ & $\begin{array}{l}\text { Extract Mitragyna speciosa possessed the strongest } \\
\text { activity without cytotoxic effect } 60.08 \pm 10.02 \% \text { and } \\
\text { cell viability, } 91,98 \pm 5.58 \%) \text {. It is noteworthy that } \\
\text { M5S1 was constituted largely by a fatty acid, in } \\
\text { particular palmitic acid }(34.90 \%) \text {, which has been } \\
\text { claimed as an anti-inflammatory compound. }\end{array}$ & [64] \\
\hline \multicolumn{3}{|r|}{ OPIATE } & \\
\hline 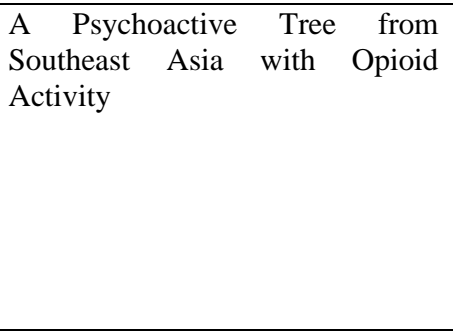 & $\begin{array}{l}\text { Kratom } \\
\text { Extract }\end{array}$ & $\begin{array}{l}\text { This study reports that date, more than } 40 \\
\text { compounds have been isolated from the leaves. The } \\
\text { major alkaloid found within the crude extract, } \\
\text { mitragynine, has been the subject of many } \\
\text { pharmacological studies. In addition to the } \\
\text { pharmacological studies, two total syntheses of } \\
\text { mitragynine have been published as well as general } \\
\text { structure-activity relationships (SARs) with respect } \\
\text { to the opioid activity. }\end{array}$ & {$[1]$} \\
\hline \multicolumn{4}{|c|}{ OPIATE WITHDRAWAL } \\
\hline $\begin{array}{l}\text { Kratom to mitragynine and its } \\
\text { derivatives: Physiological and } \\
\text { behavioural effects related to use, } \\
\text { abuse, and addiction. }\end{array}$ & Kratom leaf & $\begin{array}{l}\text { It was found that kratom consumed in a systematic } \\
\text { manner aims to increase tolerance for hard work or as } \\
\text { a substitute for self-medication for opioid addiction. } \\
\text { There is also evidence from animal models that } \\
\text { support analgesics, muscle relaxants, anti- } \\
\text { inflammatory and strong anorectic effects. } \\
\text { Mitragynine and its derivatives actions in the central } \\
\text { nervous system involve } \mu \text {-opioid receptors, neuronal } \\
\mathrm{Ca}^{2+} \text { channels, and descending monoaminergic } \\
\text { projections. }\end{array}$ & [11] \\
\hline $\begin{array}{l}\text { Kratom use and mental health: A } \\
\text { systematic review. }\end{array}$ & Kratom leaf & $\begin{array}{l}\text { This study reports that kratom's potential as a harm } \\
\text { reduction tool, most notably as a substitute for opioids } \\
\text { among people who are addicted. Kratom also enhances } \\
\text { mood and relieves anxiety among many users. For } \\
\text { many, kratom's negative mental health effects - } \\
\text { primarily withdrawal symptoms - appear to be mild } \\
\text { relative to those of opioids. For some users, however, } \\
\text { withdrawal is highly uncomfortable, and maintaining } \\
\text { abstinence becomes difficult. }\end{array}$ & [16] \\
\hline $\begin{array}{l}\text { The informal use of ketum } \\
\text { (Mitragyna speciosa) for opioid } \\
\text { withdrawal in the northern states } \\
\text { of peninsular Malaysia and } \\
\text { implications for drug substitution } \\
\text { therapy. }\end{array}$ & Kratom leaf & $\begin{array}{l}\text { This study reports that kratom users were relatively } \\
\text { older (mean } 38.7 \text { years) than the larger substance- } \\
\text { using group. Nearly } 77 \% \text { ( } 104 \text { subjects) had previous } \\
\text { drug use history, whilst urine screening confirmed } 62 \\
\text { subjects were also using other substances. Longer- } \\
\text { term users (use }>2 \text { years) had higher odds of being } \\
\text { married, of consuming more than the average three } \\
\text { glasses of ketum a day, and reporting better appetite. } \\
\text { Short-term users had higher odds of having ever used } \\
\text { heroin, testing positive for heroin, and of using ketum } \\
\text { to reduce addiction to other drugs. }\end{array}$ & {$[65]$} \\
\hline $\begin{array}{l}\text { Mitragynine reduced morphine- } \\
\text { induced conditioned place } \\
\text { preference and withdrawal in } \\
\text { rodents }\end{array}$ & Mitragynine & $\begin{array}{l}\text { This study aimed to provide an evaluation of abuse } \\
\text { liability and the potential of mitragynine in the } \\
\text { treatment for opioid addictions. The results showed } \\
\text { after being given morphine to rat, } 10 \mathrm{mg} / \mathrm{kg} \\
\text { mitragynine could reduce jumping behavior to the } \\
\text { same level as chronic treatment of } 10 \mathrm{mg} / \mathrm{kg} \\
\text { mitragynine alone, and } 30 \mathrm{mg} / \mathrm{kg} \text { mitragynine could } \\
\text { reduce Straub tail reaction. This study indicates that } \\
\text { mitragynine had low abuse liability and could } \\
\text { attenuate the acquisition and expression of morphine- } \\
\text { induced conditioned place preference and precipitated } \\
\text { withdrawal symptoms. }\end{array}$ & [66] \\
\hline \multicolumn{3}{|c|}{ ANTIMICROBA } & \\
\hline $\begin{array}{l}\text { Evaluation of Antioxidant and } \\
\text { Antibacterial Activities of } \\
\text { Aqueous, Methanolic and } \\
\text { Alkaloid Extracts from Mitragyna }\end{array}$ & $\begin{array}{l}\text { Kratom } \\
\text { Extract }\end{array}$ & $\begin{array}{l}\text { In this study, the antimicrobial of kratom showed } \\
\text { activity against Salmonella typhi and Bacillus subtilis. } \\
\text { The minimum inhibitory concentrations (MICs) of } \\
\text { extracts determined by the broth dilution method }\end{array}$ & {$[21]$} \\
\hline
\end{tabular}




\begin{tabular}{|c|c|c|c|}
\hline $\begin{array}{l}\text { speciosa (Rubiaceae } \\
\text { Leaves }\end{array}$ & & $\begin{array}{l}\text { ranged from } 3.12 \text { to } 6.25 \mathrm{mg} / \mathrm{mL} \text {. The alkaloid extract } \\
\text { was found to be most effective against all of the tested } \\
\text { organisms. }\end{array}$ & \\
\hline $\begin{array}{l}\text { Antibacterial activities of kratom } \\
\text { leaf extract Mitragyna } \\
\text { korth) against } \quad \text { bacteria } \\
\text { propionibacterium } \\
\text { Acnes causes acne. }\end{array}$ & $\begin{array}{l}\text { Kratom } \\
\text { Extract }\end{array}$ & $\begin{array}{l}\text { The results showed that the thick extract of kratom leaf } \\
\text { had an inhibitory effect on the growth of Escherichia } \\
\text { Coli bacteria and the kratom leaf extract was able to } \\
\text { inhibit the growth of Propionibacterium acnes at a } \\
\text { concentration of } 5 \% \text { with a diameter of inhibition of } \\
8.6 \mathrm{~mm} \pm 0,20 \text {. }\end{array}$ & [67] \\
\hline \multicolumn{4}{|c|}{ ANTIOXIDANT } \\
\hline $\begin{array}{l}\text { Evaluation of Antioxidant and } \\
\text { Antibacterial Activities of } \\
\text { Aqueous, Methanolic and } \\
\text { Alkaloid Extracts from Mitragyna } \\
\text { speciosa (Rubiaceae Family) } \\
\text { Leaves }\end{array}$ & $\begin{array}{l}\text { Kratom } \\
\text { Extract }\end{array}$ & $\begin{array}{l}\text { The extracts showed antioxidant activities were } \\
\text { correlated with the total phenolic content. This result } \\
\text { suggests that the relatively high antioxidant activity of } \\
\text { the methanolic extract compared to aqueous and } \\
\text { alkaloid extract could be possibly be due to its high } \\
\text { phenolic content. }\end{array}$ & [21] \\
\hline $\begin{array}{l}\text { Characterization, Phytochemical } \\
\text { Screenings and Antioxidant } \\
\text { Activity Test of Kratom Leaf } \\
\text { Ethanol Extract (Mitragyna } \\
\text { speciosa Korth) Using DPPH } \\
\text { Method }\end{array}$ & $\begin{array}{l}\text { Kratom } \\
\text { Extract }\end{array}$ & $\begin{array}{l}\text { The results showed phytochemical screening } \\
\text { containing kratom leaf ethanol extract containing } \\
\text { chemical composition: alkaloids, flavonoids, } \\
\text { triterpenoids/steroids, saponins, and tannins. The } \\
\text { results of antioxidant activity testing showed that } \\
\text { ethanol extract had an } \mathrm{IC}_{50} \text { value of } 38.56 \mu \mathrm{g} / \mathrm{ml} \text {. } \\
\text { These results indicate that the kratom ethanol extract } \\
\text { has strong antioxidant activity. }\end{array}$ & [68] \\
\hline \multicolumn{4}{|c|}{$\begin{array}{l}\text { Glutathione Transferase (GSTs) OBLIGATOR } \\
\end{array}$} \\
\hline $\begin{array}{l}\text { In Vitro and in Vivo Effects of } \\
\text { Three Different Mitragyna } \\
\text { speciosa Korth Leaf Extracts on } \\
\text { Phase II Drug Metabolizing } \\
\text { Enzymes-Glutathione } \\
\text { Transferases (GSTs) }\end{array}$ & \begin{tabular}{|l|} 
Kratom \\
Extract
\end{tabular} & $\begin{array}{l}\text { At the highest concentration used, the methanolic } \\
\text { extract showed the highest GSTs specific activity } \\
\text { inhibition }(61 \%) \text {, followed by aqueous }(50 \%) \text { and total } \\
\text { alkaloid extract }(43 \%) \text {, respectively. In in vivo study, } \\
\text { three different dosages; } 50,100 \text {, and } 200 \mathrm{mg} / \mathrm{kg} \text { for } \\
\text { methanolic and aqueous extracts and } 5,10 \text {, and } 20 \\
\mathrm{mg} / \mathrm{kg} \text { for total alkaloid extract were given orally for } \\
14 \text { days. An increase in GST specific activity was } \\
\text { generally observed. However, only Mitragyna } \\
\text { speciosa aqueous extract with a dosage of } 100 \mathrm{mg} / \mathrm{kg} \\
\text { showed significant results: } 129 \% \text { compared to control. }\end{array}$ & [34] \\
\hline
\end{tabular}

\subsection{Pharmacokinetics.}

The use of mitragynine is relatively safe at lower sub-chronic doses $(1-10 \mathrm{mg} / \mathrm{kg}) \mathrm{but}$ shows toxicity at the highest dose (sub-chronic 28 days: $100 \mathrm{mg} / \mathrm{kg}$ ) [8]. But there is no literature related to the use of safe doses of kratom in humans. Trakulsrichai et al. (2015) conducted a study of pharmacokinetic parameters in mitragynine showing time to reach maximum plasma concentrations ( $0.83 \pm 0.35$ hours), terminal half-life ( $23.24 \pm 16.07$ hours), and clear volume distribution (38, $04 \pm 24.32 \mathrm{~L} / \mathrm{kg}$ ) [69]. Prutipanlai et al. (2017) conducted a determination of mitragynine in urine, which showed mitragynine recovery ranged from $92.75-$ $100.83 \%$ [70]. Mitragynine concentration-time data showed two peak plasma concentrations (Cmax). The first Cmax 457.2 $\pm 42.3(\mathrm{ng} / \mathrm{mL})$ occurred within $1.5 \mathrm{~h}$ postdose, while the second Cmax $335.0 \pm 34.3(\mathrm{ng} / \mathrm{mL}$ ) occurred between 2.8 to $3.8 \mathrm{~h}$ post-dose [71]. Research Manda et al. (2014) conducted in vitro research showing mitragynine, 7-hydroxymitragynine, and mitraphylline were unstable in gastric fluid simulation but stable in intestinal fluid simulation, 7-hydroxymitragynine decomposed $27 \%$ in gastric fluid simulation, $23 \%$ were converted to mitragynine, and 6\% decompose in intestinal fluid simulation [72]. Meanwhile, mitraphylline is stable in gastric fluid simulation but is not stable in intestinal fluid simulation. Mitragynine, 7-hydroxymitragynine, and mitraphylline have high plasma bonds (> 90\%). Mitragynine is stable in the human liver microsome. Instead, 7-hydroxymitragynine, and mitraphylline are metabolized by human liver microsome with a half-life of 24 and 50 minutes. Mitragynine and 7-hydroxymitragynine inhibit P-glycoprotein with EC50 values of $18.2 \pm 3.6 \mathrm{M}$ and $32.4 \pm 1.9$ $\mathrm{M}$, respectively, determined by the fluorescent calcein-AM test, while no inhibition was seen 
with mitraphylline. These data indicate the possibility of drug interaction if mitragynine and 7hydroxymitragynine are coadministered with drugs that are P-glycoprotein substrates.

\subsection{Analysis.}

Kratom contains more than 40 types of alkaloids including Mitragyna speciosa, as many as $(66.2 \%)$ and their derivatives, speciogynine $(6.6 \%)$, speciociliatine $(0.8 \%)$, paynantheine $(8.6 \%)$, 7- hydroxy mitragynine $(2 \%, 0 \%)$. The number of compounds in Mitragyna speciosa can be influenced by geographical factors. As in Boffa et al. (2018) research studied five different strains of Mitragyna speciosa that have different vein colors and geographic origin; Red Thai, Red Malay, Red Bali, White Borneo, and Green Malay, showed the Green Malay variety highest w/w percentages for mitragynine and total alkaloids in its extracts [73]. In addition to geographical factors that affect the compound content of Mitragyna speciosa, temperature, and $\mathrm{pH}$ factors greatly affect the stability of the compound. The study of Basilieri et al. (2020) found that mitragynine was completely stable for eight hours at $\mathrm{pH} 2$ 10 at 4,20 , and $40^{\circ} \mathrm{C}$ [74]. In contrast, the drug was significantly acid-labile at elevated temperatures $\left(60-80^{\circ} \mathrm{C}\right)$.

Kratom alkaloid extract can be obtained through a withdrawal process with conventional and nonconventional methods because each method has its advantages and disadvantages. As in research of Idayu et al. (2011) carried out the withdrawal of kratom alkaloid extract compounds conventionally by using absolute methanol for 72 hours [75]. The methanol extract was dissolved in a $10 \%$ acetic acid solution, left for 24 hours, and filtered to produce acid filtrate. The acid filtrate is washed with petroleum ether, made into a base ( $\mathrm{pH} 9)$ with $25 \%$ ammonia solution, and extracted with chloroform. The combined chloroform extract was washed with distilled water, dried with anhydrous sodium sulfate, and evaporated to produce $0.73 \%(\mathrm{w} / \mathrm{w})$ crude alkaloid extract. The main alkaloids were isolated by silica gel eluting column chromatography with diethyl ether identified as mitragynine by standard spectroscopic methods. Overall, mitragynine yields around $0.087 \%(\mathrm{w} / \mathrm{w})$ of fresh leaf weight. The same study was also carried out by Azizi et al. (2010) Mitragyna speciosa (5 kg) dry powder soaked in methanol for several days at room temperature [34]. The extraction and evaporation procedures were repeated three times. Next, one part of methanol extract was mixed with 35 parts, $90 \%$ acetic acid. The suspension is filtered, and the filtrate is washed with petroleum ether. The acid layer is refined with sodium carbonate to $\mathrm{pH} 9$ and extracted with chloroform several times. The combined chloroform extract was dried over sodium sulfate and evaporated to produce $5 \mathrm{~g}$ (yield of $0.5 \%$ ) of the crude alkaloid mixture. In the research, Parthasarathy et al. (2013) produced mitragynine in plant extracts ranging from 0.8 to $25 \mathrm{mg} / \mathrm{g}$ monitored using the High-Performance Liquid Chromatography with Diode Array Detector (HPLC-DAD) system with Inertsil C8 (4.6 mm $150 \mathrm{~mm}, 5 \mathrm{~mm})$ as the column and mixture of acetonitrile and formic acid, 50:50 (v/v) as the mobile phase [10]. Whereas other studies conducted extracts of alkaloid extracts from kratom using nonconventional methods such as in the study of Tohar et al. (2007) kratom powder was saturated with $\mathrm{NH}_{3}$, Supercritical Carbon Dioxide Extraction (ethanol 20) at $40^{\circ} \mathrm{C}$ and 5000 psi pressure [76]. Overall, the yield of kratom alkaloids is around $4.05 \%$ (w/w) of the weight of fresh leaves. The study of Orio et al. (2012) also withdrew alkaloid extracts from kratom using ultrasound-assisted extraction (UAE), microwave-assisted extraction (MAE), and SFE- $\mathrm{CO}_{2}$ supercritical carbon dioxide extraction, using a mixture of methanol, ethanol, water, and binary mixtures [77]. Of the several methods tested, MAE in a closed vessel at $110 \mathrm{C}(60 \mathrm{~W}$, methanol/water 1:1) gave the highest kratom 
alkaloid extract $16.6 \pm 0.41 \mathrm{mg} / \mathrm{g}$ dried leaves, while UAE with an immersion horn at $25 \mathrm{C}$ $(21.4 \mathrm{kHz}, 50 \mathrm{~W}$, methanol) showed the best yield for mitragynine. Another study was also conducted by Abd Razak et al. (2020) to optimize the results of the crude methanol extract of Mitragyna speciosa leaves using extraction with the help of USG (UEA) [78]. The results showed the maximum yield of $49.72 \%$ at the optimal conditions (temperature, $34{ }^{\circ} \mathrm{C}$; time, 25 min; and volume of solvent, $166 \mathrm{~mL}$ ). Withdrawal of kratom alkaloid extract compounds using nonconventional methods results in relatively higher yields and faster processing than using conventional methods but has the disadvantages of using high technology and high costs.

\section{Conclusions}

In general, kratom leaves have the potential to become the raw material for new drugs because kratom leaves contain mitragynine compounds that have many benefits of pharmacological effects. However, the use of kratom leaves directly in the form of powder or fresh leaves can increase the risk of toxicity because the quality and dosage of kratom in leaf form have not been scientifically standardized. Therefore the recommended use as a drug raw material in the world of health is isolated from the compound mitragynine, whose dosage can be adjusted easily depending on the intended use and desired pharmacological effects.

\section{Funding}

This research received no external funding.

\section{Acknowledgments}

The author would like to thank the Hazanah Foundation and Sekolah Tinggi Farmasi Indonesia for all the support and direction that allowed me to finish this paper.

\section{Conflicts of Interest}

The authors declared no conflict of interest.

\section{References}

1. Jessica, E.; Adkins, E.W. Mitragyna speciosa, A Psychoactive Tree from Southeast Asia with Opioid Activity. Current Topics in Medicinal Chemistry 2011, 11, 1165-1175, https://doi.org/10.2174/156802611795371305.

2. Shellard, E.J. Ethnopharmacology of kratom and the Mitragyna alkaloids. Journal of Ethnopharmacology 1989, 25, 123-124, https://doi.org/10.1016/0378-8741(89)90053-6.

3. Jansen, K.L.; Prast, C.J. Ethnopharmacology of kratom and the Mitragyna alkaloids. Journal of Ethnopharmacology 1988, 23, 115-119, https://doi.org/10.1016/0378-8741(88)90121-3.

4. Reanmongkol, W.; Keawpradub, N.; Sawangjaroen, K. Effects of the extracts from Mitragyna speciosa Korth. leaves on analgesic and behavioral activities in experimental animals. J. Sci. Technol 2007, 29, 3948.

5. Chee, J. W.; Amirul, A.A.; Majid, M.I.A.; Mansor, S.M. Factors influencing the release of Mitragyna speciosa crude extracts from biodegradable $\mathrm{P}$ (3HB-co-4HB). International journal of pharmaceutics $\mathbf{2 0 0 8}$, 361,1-6, https://doi.org/10.1016/j.ijpharm.2008.05.007.

6. Takayama, H. Chemistry and pharmacology of analgesic indole alkaloids from the rubiaceous plant, Mitragyna speciosa. Chemical and Pharmaceutical Bulletin 2004, 52, 916-928, https://doi.org/10.1248/cpb.52.916.

7. Kikura-Hanajiri, R.; Kawamura, M.; Maruyama, T.; Kitajima, M.; Takayama, H.; Goda, Y. Simultaneous analysis of mitragynine, 7-hydroxymitragynine, and other alkaloids in the psychotropic plant "kratom"(Mitragyna speciosa) by LC-ESI-MS. Forensic toxicology 2009, 27, 67-74, https://doi.org/10.1007/s11419-009-0070-5. 
8. Sabetghadam, A.; Ramanathan, S.; Sasidharan, S.; Mansor, S.M. Subchronic exposure to mitragynine, the principal alkaloid of Mitragyna speciosa, in rats. Journal of ethnopharmacology 2013, 146, 815-823, https://doi.org/10.1016/j.jep.2013.02.008.

9. Warner, M.L.; Kaufman, N.C.; Grundmann, O. The pharmacology and toxicology of kratom: from traditional herb to drug of abuse. International journal of legal medicine 2016, 130, 127-138, https://doi.org/10.1007/s00414-015-1279-y

10. Parthasarathy, S.; Ramanathan, S.; Murugaiyah, V.; Hamdan, M.R.; Said, M.I.M.; Lai, C.S.; Mansor, S.M. A simple HPLC-DAD method for the detection and quantification of psychotropic mitragynine in Mitragyna speciosa (ketum) and its products for the application in forensic investigation. Forensic science international 2013, 226, 183-187, https://doi.org/10.1016/j.forsciint.2013.01.014

11. Hassan, Z.; Muzaimi, M.; Navaratnam, V.; Yusoff, N.H.; Suhaimi, F.W.; Vadivelu, R.; Jayabalan, N. From Kratom to mitragynine and its derivatives: physiological and behavioural effects related to use, abuse, and addiction. Neuroscience \& Biobehavioral Reviews 2013, 37, 138-151, https://doi.org/10.1016/j.neubiorev.2012.11.012.

12. Tanguay, P. Kratom in Thailand. International Drug Policy Consortium 2011, http://dx.doi.org/10.2139/ssrn.1908849

13. Shamima, A. R.; Fakurazi, S.; Hidayat, M.T.; Hairuszah, I.; Moklas, M.A.M.; Arulselvan, P. Antinociceptive action of isolated mitragynine from Mitragyna speciosa through activation of opioid receptor system. International journal of molecular sciences 2012, 13, 11427-11442, https://doi.org/10.3390/ijms130911427.

14. Carpenter, J.M.; Criddle, C.A.; Craig, H.K.; Ali, Z.; Zhang, Z.; Khan, I.A.; Sufka, K.J. Comparative effects of Mitragyna speciosa extract, mitragynine, and opioid agonists on thermal nociception in rats. Fitoterapia 2016, 109, 87-90, https://doi.org/10.1016/j.fitote.2015.12.001.

15. Yue, K.; Kopajtic, T.A.; Katz, J.L. Abuse liability of mitragynine assessed with a self-administration procedure in rats. Psychopharmacology 2018, 235, 2823-2829, https://doi.org/10.1007/s00213-018-49749.

16. Swogger, M.T.; Walsh, Z. Kratom use and mental health: A systematic review. Drug and Alcohol Dependence 2018, 183, 134-140, https://doi.org/10.1016/j.drugalcdep.2017.10.012.

17. Annas, S.; Mossadeq, W.M.S.; Kadir, A.A. Antipyretic Effect of Mitragynine and Crude Methanolic Extract of Mitragyna speciosa Korth. in Mice. Pertanika Journal of Tropical Agricultural Science 2020, 43, 207216.

18. Moklas, M.A.M.; Nurul Raudzah, A.R.; Taufik, H.M.; Sharida, F.; Farah, I.N.; Zulkhairi, A.; Shamima, A.R. A preliminary toxicity study of mitragynine, an alkaloid from Mitragyna speciosa Korth and its effects on locomotor activity in rats. Adv. Med. Dent Sci 2008, 2, 56-60.

19. Mossadeq, W.S.; Sulaiman, M.R.; Mohamad, T.T.; Chiong, H.S.; Zakaria, Z.A.; Jabit, M.L.; Israf, D.A. Anti-inflammatory and antinociceptive effects of Mitragyna speciosa Korth methanolic extract. Medical Principles and Practice 2009, 18, 378-384, https://doi.org/10.1159/000226292.

20. Suhaimi, S.; Kartikasari, D. Granul Antidiare Test from Kratom Leaf Ethanol Extract (Mytragina specioca Korth) again to Mice White Male (Mus musculus L). Jurnal Ilmu Kefarmasian Indonesia 2020, 18, 101-108, https://doi.org/10.35814/jifi.v18i1.787.

21. Parthasarathy, S.; Bin, A.J.; Ramanathan, S.; Ismail, S.; Sasidharan, S.; Said, M.I.M.; Mansor, S.M. Evaluation of antioxidant and antibacterial activities of aqueous, methanolic and alkaloid extracts from Mitragyna speciosa (Rubiaceae family) leaves. Molecules 2009, 14, 3964-3974, https://doi.org/10.3390/molecules14103964.

22. Oberbarnscheidt, T.; Miller, N.S. Kratom-A Lethal Drug on the Rise. J Addiction Prevention $2019,7$.

23. Fluyau, D.; Revadigar, N. Biochemical benefits, diagnosis, and clinical risks evaluation of kratom. Frontiers in Psychiatry 2017, 8, https://doi.org/10.3389/fpsyt.2017.00062.

24. Osborne, C.S.; Overstreet, A.N.; Rockey, D.C.; Schreiner, A.D. Drug-induced liver injury caused by kratom use as an alternative pain treatment amid an ongoing opioid epidemic. Journal of investigative medicine high impact case reports 2019, 7, https://doi.org/10.1177/2324709619826167.

25. Aggarwal, G.; Robertson, E.; McKinlay, J.; Walter, E. Death from Kratom toxicity and the possible role of intralipid. Journal of the Intensive Care Society 2018, 19, 61-63, https://doi.org/10.1177/1751143717712652.

26. Nelsen, J.L.; Lapoint, J.; Hodgman, M.J.; Aldous, K.M. Seizure and coma following Kratom (Mitragynina speciosa Korth) exposure. Journal of Medical Toxicology 2010, 6, 424-426, https://doi.org/10.1007/s13181010-0079-5.

27. McIntyre, I.M.; Trochta, A.; Stolberg, S.; Campman, S.C. Mitragynine 'Kratom'related fatality: a case report with postmortem concentrations. Journal of analytical toxicology 2015, 39, 152-155, https://doi.org/10.1093/jat/bku137.

28. Tungtananuwat, W.; Lawanprasert, S. Fatal 4x100; home-made kratom juice cocktail. Journal of Health Research 2010, 24, 43-47.

29. Kronstrand, R.; Roman, M.; Thelander, G.; Eriksson, A. Unintentional fatal intoxications with mitragynine and O-desmethyltramadol from the herbal blend Krypton. Journal of analytical toxicology 2011, 35,242247, https://doi.org/10.1093/anatox/35.4.242. 
30. Karinen, R.; Fosen, J.T.; Rogde, S.; Vindenes, V. An accidental poisoning with mitragynine. Forensic science international 2014, 245, e29-e32, https://doi.org/10.1016/j.forsciint.2014.10.025.

31. Holler, J.M.; Vorce, S.P.; McDonough-Bender, P.C.; Magluilo, Jr.J.; Solomon, C.J.; Levine, B. A drug toxicity death involving propylhexedrine and mitragynine. Journal of analytical toxicology 2011, 35, 54-59, https://doi.org/10.1093/anatox/35.1.54.

32. Cinosi, E.; Martinotti, G.; Simonato, P.; Singh, D.; Demetrovics, Z.; Roman-Urrestarazu, A.; Yu, W.J. Following "the roots" of Kratom (Mitragyna speciosa): the evolution of an enhancer from a traditional use to increase work and productivity in Southeast Asia to a recreational psychoactive drug in western countries. BioMed research international 2015, 3, 1-11, https://doi.org/10.1155/2015/968786.

33. Corkery, J.M.; Streete, P.; Claridge, H.; Goodair, C.; Papanti, D.; Orsolini, L.; Hendricks, A. Characteristics of deaths associated with kratom use. Journal of psychopharmacology 2019, 33, 1102-1123, https://doi.org/10.1177/0269881119862530.

34. Azizi, J.; Ismail, S.; Mordi, M.N.; Ramanathan, S.; Said, M.I.M.; Mansor, S.M. In vitro and in vivo effects of three different Mitragyna speciosa Korth leaf extracts on phase II drug metabolizing enzymesglutathione transferases (GSTs). Molecules 2010, 15, 432-441, https://doi.org/10.3390/molecules15010432.

35. Harizal, S.N.; Mansor, S.M.; Hasnan, J.; Tharakan, J.K.J.; Abdullah, J. Acute toxicity study of the standardized methanolic extract of Mitragyna speciosa Korth in rodent. Journal of ethnopharmacology 2010, 131, 404-409, https://doi.org/10.1016/j.jep.2010.07.013.

36. Sabetghadam, A.; Ramanathan, S.; Sasidharan, S.; Mansor, S.M. Subchronic exposure to mitragynine, the principal alkaloid of Mitragyna speciosa, in rats. Journal of ethnopharmacology 2013, 146, 815-823, https://doi.org/10.1016/j.jep.2013.02.008.

37. Singh, D.,; Müller, C.P.; Vicknasingam, B.K. Kratom (Mitragyna speciosa) dependence, withdrawal symptoms and craving in regular users. Drug and alcohol dependence 2014, 139, 132-137, https://doi.org/10.1016/j.drugalcdep.2014.03.017.

38. McWhirter, L.; Morris, S. A case report of inpatient detoxification after kratom (Mitragyna speciosa) dependence. European addiction research 2010, 16, 229-231, https://doi.org/10.1159/000320288.

39. Yusoff, N.H.; Suhaimi, F.W.; Vadivelu, R.K.; Hassan, Z.; Rümler, A.; Rotter, A.; Müller, C.P. Abuse potential and adverse cognitive effects of mitragynine (kratom). Addiction biology 2016, 21, 98-110, https://doi.org/10.1111/adb.12185.

40. Hemby, S.E.; McIntosh, S.; Leon, F.; Cutler, S.J.; McCurdy, C.R. Abuse liability and therapeutic potential of the Mitragyna speciosa (kratom) alkaloids mitragynine and 7-hydroxymitragynine. Addiction Biology 2019, 24, 874-885, https://doi.org/10.1111/adb.12639

41. Ahmad, K.; Aziz, Z. Mitragyna speciosa use in the northern states of Malaysia: a cross-sectional study. Journal of Ethnopharmacology 2012, 141, 446-450, https://doi.org/10.1016/j.jep.2012.03.009.

42. Singh, D.; Narayanan, S.; Müller, C.P.; Vicknasingam, B.; Yücel, M.; Ho, E.T.W.; Mansor, S.M. Long-term cognitive effects of Kratom (Mitragyna speciosa Korth.) use. Journal of psychoactive drugs 2019, 51, 1927, https://doi.org/10.1080/02791072.2018.1555345.

43. Singh, D.; Narayanan, S.; Müller, C.P.; Swogger, M.T.; Rahim, A.A.; Leong Bin Abdullah, M.F.I.; Vicknasingam, B.K. Severity of kratom (Mitragyna speciosa Korth.) psychological withdrawal symptoms. Journal of psychoactive drugs 2018, 50, 445-450, https://doi.org/10.1080/02791072.2018.1511879

44. Singh, D.; Damodaran, T.; Prozialeck, W.C.; Grundmann, O.; Karunakaran, T.; Vicknasingam, B. Constipation prevalence and fatigue severity in regular kratom (Mitragyna speciosa Korth.) users. Journal of Substance Use 2019, 24(3), 233-239, https://doi.org/10.1080/14659891.2018.1546340.

45. Cheaha, D.; Keawpradub, N.; Sawangjaroen, K.; Phukpattaranont, P.; Kumarnsit, E. Effects of an alkaloidrich extract from Mitragyna speciosa leaves and fluoxetine on sleep profiles, EEG spectral frequency and ethanol withdrawal symptoms in rats. Phytomedicine 2015, 22, 1000-1008, https://doi.org/10.1016/j.phymed.2015.07.008.

46. Hidayati, A. Sedative Effect Test of N-Hexane Extract from Kratom (Mitragyna speciosa Korth.) Leaves in Balb/c strain male mice. Doctoral dissertation, Tanjungpura University 2013, 3.

47. Novindriani, D. Kratom leaf infusion (Mitragyna speciosa) sedative effect test on Balb/C strain male mice. Doctoral dissertation, Tanjungpura Universit) 2014, 3.

48. Ridayani, Y. Test the sedative effect of the ethanol fraction of kratom leaves (Mitragyna speciosa Korth.) In male BALB / c mice. Doctoral dissertation, Tanjungpura University 2013, 3.

49. Kumarnsit, E.; Keawpradub, N.; Nuankaew, W. Acute and long-term effects of alkaloid extract of Mitragyna speciosa on food and water intake and body weight in rats. Fitoterapia 2006, 77, 339-345, https://doi.org/10.1016/j.fitote.2006.04.006.

50. Compton, D. M.; Garcia, C.; Kamaratos, A.; Johnson, B.G.; Wedge, T. An examination of the consequences of chronic exposure to Mitragyna speciosa during adolescence on learning and memory in adulthood. $J$ Phytopharmacol 2014, 3, 300-309.

51. Ikhwan, D.; Harlia, W.A. Characterization of cytotoxic compounds from ethyl acetate fraction of Kratom leaves (Mitragyna speciosa Korth.) And their activity against T47D breast cancer cells. Jurnal Kimia Khatulistiwa 2018, 7, 18-24. 
52. Kumarnsit, E.; Vongvatcharanon, U.; Keawpradub, N.; Intasaro, P. Fos-like immunoreactivity in rat dorsal raphe nuclei induced by alkaloid extract of Mitragyna speciosa. Neuroscience letters 2007, 416, 128-132, https://doi.org/10.1016/j.neulet.2007.01.061.

53. Sabetghadam, A.; Ramanathan, S.; Mansor, S.M. The evaluation of antinociceptive activity of alkaloid, methanolic, and aqueous extracts of Malaysian Mitragyna speciosa Korth leaves in rats. Pharmacognosy research 2010, 2, https://doi.org/10.4103/0974-8490.65514.

54. Nugraha, W.I.; Robiyanto, R.; Luliana, S. Antinociceptive Activity of Aqueous Fraction of Kratom Leaves Mitragyna speciosa Korth.) on Male Swiss Albino Mice. Traditional Medicine Journal 2018, 23, 91-96, https://doi.org/10.22146/mot.32085.

55. Luliana, S.; Robiyanto, R.; Islamy, M.R. Antinociceptive Activity of Kratom Leaf Dichloromethane Fraction (Mitragyna speciosa Korth.) Oral Route in Swiss Male Mice. Pharmaceutical Sciences and Research 2018, 5, 58-64,

56. Matsumoto, K.; Horie, S.; Takayama, H.; Ishikawa, H.; Aimi, N.; Ponglux, D.; Watanabe, K. Antinociception, tolerance and withdrawal symptoms induced by 7-hydroxymitragynine, an alkaloid from the Thai medicinal herb Mitragyna speciosa. Life sciences 2005, 78, 2-7, https://doi.org/10.1016/j.lfs.2004.10.086.

57. Matsumoto, K.; Mizowaki, M.; Suchitra, T.; Murakami, Y.; Takayama, H.; Sakai, S. I.; Watanabe, H. Central antinociceptive effects of mitragynine in mice: contribution of descending noradrenergic and serotonergic systems. European Journal of Pharmacology 1996, 317, 75-81, https://doi.org/10.1016/S00142999(96)00714-5.

58. Matsumoto, K.; Hatori, Y.; Murayama, T.; Tashima, K.; Wongseripipatana, S.; Misawa, K.; Horie, S. Involvement of $\mu$-opioid receptors in antinociception and inhibition of gastrointestinal transit induced by 7 hydroxymitragynine, isolated from Thai herbal medicine Mitragyna speciosa. European journal of pharmacology 2006, 549, 63-70, https://doi.org/10.1016/j.ejphar.2006.08.013.

59. Matsumoto, K.; Horie, S.; Ishikawa, H.; Takayama, H.; Aimi, N.; Ponglux, D.; Watanabe, K. Antinociceptive effect of 7-hydroxymitragynine in mice: Discovery of an orally active opioid analgesic from the Thai medicinal herb Mitragyna speciosa. Life sciences 2004, 74, 2143-2155, https://doi.org/10.1016/j.lfs.2003.09.054.

60. Matsumoto, K.; Takayama, H.; Narita, M.; Nakamura, A.; Suzuki, M.; Suzuki, T.; Tashima, K. MGM-9 [(E)-methyl 2-(3-ethyl-7a, 12a-(epoxyethanoxy)-9-fluoro-1, 2, 3, 4, 6, 7, 12, 12b-octahydro-8methoxyindolo [2, 3-a] quinolizin-2-yl)-3-methoxyacrylate], a derivative of the indole alkaloid mitragynine: A novel dual-acting $\mu$-and $\kappa$-opioid agonist with potent antinociceptive and weak rewarding effects in mice. Neuropharmacology 2008, 55,154-165, https://doi.org/10.1016/j.neuropharm.2008.05.003.

61. Chittrakarn, S.; Keawpradub, N.; Sawangjaroen, K.; Kansenalak, S.; Janchawee, B. The neuromuscular blockade produced by pure alkaloid, mitragynine and methanol extract of kratom leaves (Mitragyna speciosa Korth.). Journal of Ethnopharmacology 2010, 129, 344-349, https://doi.org/10.1016/j.jep.2010.03.035.

62. Chittrakarn, S.; Sawangjaroen, K.; Prasettho, S.; Janchawee, B.; Keawpradub, N. Inhibitory effects of kratom leaf extract (Mitragyna speciosa Korth.) on the rat gastrointestinal tract. Journal of ethnopharmacology 2008, 116, 173-178, https://doi.org/10.1016/j.jep.2007.11.032.

63. Azizi, J.; Ismail, S.; Mansor, S.M. Mitragyna speciosa Korth leaves extracts induced the CYP450 catalyzed aminopyrine-N-demethylase (APND) and UDP-glucuronosyl transferase (UGT) activities in male SpragueDawley rat livers. Drug Metabolism and Personalized Therapy 2013, 28, 95-105, https://doi.org/10.1515/dmdi-2012-0039.

64. Tohar, N.; Shilpi, J.A.; Sivasothy, Y.; Ahmad, S.; Awang, K. Chemical constituents and nitric oxide inhibitory activity of supercritical carbon dioxide extracts from Mitragyna speciosa leaves. Arabian journal of chemistry 2019, 12, 350-359, https://doi.org/10.1016/j.arabjc.2016.09.005.

65. Vicknasingam, B.; Narayanan, S.; Beng, G.T.; Mansor, S.M. The informal use of ketum (Mitragyna speciosa) for opioid withdrawal in the northern states of peninsular Malaysia and implications for drug substitution therapy. International Journal of Drug Policy 2010, 21, 283-288, https://doi.org/10.1016/j.drugpo.2009.12.003.

66. Meepong, R.; Sooksawate, T. Mitragynine reduced morphine-induced conditioned place preference and withdrawal in rodents. Thai Journal of Pharmaceutical Sciences (TJPS) 2019, 43, 21-29.

67. Suhaimi, S.; Puspasari, H.; Husnani, H.; Apriani, M. Test of concentrated extract of kratom leaves (Mitragyna speciosa Korth) on Propionibacterium acnes bacteria as cause of acne. Medical Sains 2019, 4, 1-6.

68. Yuniarti, R.; Nadia, S.; Alamanda, A.; Zubir, M., Syahputra, R.A.; Nizam, M. Characterization, Phytochemical Screenings and Antioxidant Activity Test of Kratom Leaf Ethanol Extract (Mitragyna speciosa Korth) Using DPPH Method. JPhCS 2020, 1462, 012026, https://doi.org/10.1088/17426596/1462/1/012026.

69. Trakulsrichai, S.; Sathirakul, K.; Auparakkitanon, S.; Krongvorakul, J.; Sueajai, J.; Noumjad, N.; Wananukul, W. Pharmacokinetics of mitragynine in man. Drug design, development and therapy 2015, 9 , 2421, https://doi.org/10.2147/DDDT.S79658. 
70. Prutipanlai, S.; Botpiboon, O.; Janchawee, B.; Theanchaiwattana, S. Solid phase extraction method for determination of mitragynine in urine and its application to mitragynine excretion study in rats receiving caffeine. Tropical Journal of Pharmaceutical Research 2017, 16, 1675-1682, https://doi.org/10.4314/tjpr.v16i7.28.

71. Avery, B.A.; Boddu, S.P.; Sharma, A.; Furr, E.B.; Leon, F.; Cutler, S.J.; McCurdy, C.R. Comparative Pharmacokinetics of Mitragynine after Oral Adminis-tration of Mitragyna speciosa (Kratom) Leaf Extracts in Rats Authors. Planta Med 2019, 85, 340-346, https://doi.org/10.1055/a-0770-3683

72. Manda, V.K.; Avula, B.; Ali, Z.; Khan, I.A.; Walker, L.A.; Khan, S.I. Evaluation of in vitro absorption, distribution, metabolism, and excretion (ADME) properties of mitragynine, 7-hydroxymitragynine, and mitraphylline. Planta Med 2014, 80, 568-576, https://doi.org/10.1055/s-0034-1368444.

73. Boffa, L.; Ghè, C.; Barge, A.; Muccioli, G.; Cravotto, G. Alkaloid profiles and activity in different Mitragyna speciosa strains. Natural Product Communications 2018, https://doi.org/10.1177/1934578X1801300904.

74. Basiliere, S.; Kerrigan, S. Temperature and pH-Dependent Stability of Mitragyna Alkaloids. Journal of Analytical Toxicology 2020, 44(4), 314-324. https://doi.org/10.1093/jat/bkz103

75. Idayu, N.F.; Hidayat, M.T.; Moklas, M.A.M.; Sharida, F.; Raudzah, A.N.; Shamima, A.R.; Apryani, E. Antidepressant-like effect of mitragynine isolated from Mitragyna speciosa Korth in mice model of depression. Phytomedicine 2011, 18, 402-407, https://doi.org/10.1016/j.phymed.2010.08.011.

76. Tohar, N.; Devi, R.S. Supercritical Carbon Dioxide Extraction of Mitragyna speciosa Korth. Journal of Pharmacology and Experimental Therapeutics 2007. 46, 251-271,

77. Orio, L.; Alexandru, L.; Cravotto, G.; Mantegna, S.; Barge, A. UAE, MAE, SFE-CO2 and classical methods for the extraction of Mitragyna spesiosa leaves. Ultrasonics Sonochemistry 2012, 19, 591-595, https://doi.org/10.1016/j.ultsonch.2011.10.001.

78. Abd Razak, N.H.Z.1 bin Abdul Rahman, M.B.; Ashari, S.E. Optimization of Extraction Yield and Phytochemical Characterization of Crude Methanolic Extract and Its Fractions of Mitragyna Speciosa Leaves. BMC Chemistry 2020, https://doi.org/10.21203/rs.3.rs-52121/v1 